\title{
EVALUATION OF BIOETHANOL PRODUCTION FROM Eucalyptus WOOD WITH Saccharomyces cerevisiae AND SACSV-10 ${ }^{1}$
}

\author{
Sylvia Enid Vazquez ${ }^{2 *}$, Luciana Buxedas², Silvana Bonifacino², Maria Belen Ramirez ${ }^{2}$, Ana Lopez ${ }^{2}$ and \\ Mary Lopretti
}

\footnotetext{
${ }^{1}$ Received on 31.03.2016 accepted for publication on 24.08.2017.

${ }^{2}$ Universidade de la República, Departamento de Técnicas nuclear aplicado em Bioquímica e Biotecnologia, Montevideo, Uruguay. E-mail:<sylvia.vazquez.zeballos@gmail.com>,<luciana_mbr@hotmail.com>, <silvana.bonifacino@gmail.com>, <ramirezmariabelen@gmail.com>,<alopez@latu.org.uy>and <mlopretti@gmail.com>.

*Corresponding author.
}

\begin{abstract}
Eucalyptus spp. residues of paper industry are a potential lignocellulosic raw material for production of second-generation bioethanol as an alternative to conventional production from cereal crops. Studying the behavior at $40{ }^{\circ} \mathrm{C}$ of a commercial cellulase (Sunson), Eucalyptus sawdust saccharification was carried out under two $\mathrm{pH}$ conditions. With the aim to evaluate the bioethanol production from Eucalyptus wood, a strategy combining saccharification and Simultaneous Saccharification and Fermentation (SSF) was undertaken at $40{ }^{\circ} \mathrm{C}$ with a thermotolerant Saccharomyces cerevisiae with different substrate and inoculum concentrations, and different nitrogen sources. At last, the process was carried out in optimal conditions with Saccharomyces cerevisiae M522 and SacSV-10. Saccharification produced more free glucose at $\mathrm{pH} 5$, reaching a maximum of $1.5 \mathrm{~g} / \mathrm{L}$. Encouraging results were obtained with $500 \mathrm{mg} / \mathrm{L}$ of ammonium sulphate as a nitrogen source and $10 \% \mathrm{v} / \mathrm{v}$ initial inoculum at $10^{6} \mathrm{cfu} / \mathrm{mL}$ concentration. Yeast SacSV-10 was not inhibited by phenols present in the culture media using a wood concentration of $10 \mathrm{~g} / \mathrm{L}$, but when the solids concentration was increased, the bioprocess yield was compromised. When the process was carried out in optimal conditions the bioethanol production, expressed as the conversion percentage of cellulose to ethanol, was $71.5 \%$ and $73.6 \%$ for M522 and the mutant strain respectively. The studied properties of the mutant strain provide added value to it, which pose new challenges to national companies dedicated to the production and sale of inputs for bioethanol industry.
\end{abstract}

Keywords: second-generation bioethanol, cellulases, Simultaneous Saccharification and Fermentation.

\section{AVALIAÇÃO DA PRODUÇÃO DE BIOETANOL A PARTIR DE MADEIRA DE Eucalyptus COM Saccharomyces cerevisiae E SACSV-10}

\begin{abstract}
RESUMO - Resíduos de Eucalyptus da indústria de papel são resíduos lignocelulósicos potenciais para a produção de bioetanol de segunda geração, como alternativa à produção convencional de culturas de cereais. Estudando o comportamento a $40^{\circ} \mathrm{C}$ de uma celulase comercial (Sunson), a sacarificação de serragem de Eucalyiptus foi conduzida em duas condições de pH. A fim de avaliar a produção de bioetanol a partir de madeira de Eucalyptus foi realizada uma estratégia que combina a sacarificação, sacarificação e fermentação simultâneas $a 40^{\circ} \mathrm{C}$, com uma Saccharomyces cerevisiae tolerante à temperatura e com diferentes concentrações de substrato e de inóculo, e diferentes fontes de azoto. Em seguida, o processo foi realizado em condições ótimas com Saccharomyces cerevisiae M522 e SacSV-10. A sacarificação produziu mais glicose livre em pH 5, atingindo um máximo de $1,5 \mathrm{~g} / \mathrm{L}$. Resultados promissores foram obtidos com $500 \mathrm{mg} / \mathrm{L}$ de sulfato de amónio como fonte de azoto e $10 \% \mathrm{v} / \mathrm{v}$ de inoculo, a uma concentração de $10^{6} \mathrm{ufc} / \mathrm{mL}$. A levedura SacSV10 não foi inibida por fenóis presentes no meio de cultura, utilizando uma concentração de madeira de $10 \mathrm{~g} / \mathrm{l}$, mas quando a concentração de sólidos aumentou, o desempenho bioprocesso foi comprometido. Quando o processo é realizado em condições ótimas, a produção de bioetanol expressada como a percentagem de conversão de celulose para etanol foi de 71,5\% e 73,6\% para as estirpes mutantes e M522 respectivamente.
\end{abstract}


As propriedades concedidas à tensão estudou, vai agregar valor, criando novos desafios para as empresas nacionais que se dedicam à produção e venda de insumos para a indústria do bioetanol

Palavras-Chave: Bioetanol de segunda geração; Celulases; Sacarificação e fermentação simultâneas.

\section{INTRODUCTION}

Eucalyptus spp. residues of paper industry are a potential lignocellulosic raw material for production of second-generation bioethanol as an alternative to conventional production from cereal crops. The recently setting up of cellulose paste production industries in our country has considerably enhanced the Eucalyptus grandis waste production, capable to be used as biomass for biofuels production. In this way, wood has to be pretreated and saccharified before it is fermented (Sánchez et al., 2005; Cuervo et al., 2009; Carreón et al., 2009; Fernández et al., 2011). First of all, the material has to be treated before its later hydrolysis (Zhu et al., 2012; Haghighi et al., 2013). The pretreatment removes or redistributes lignin, one of the principal vegetable wall's components besides carbohydrates (Leonowicz et al., 1999; Ortiz, 2009).

Bioethanol can be produced in different ways. Traditionally the cellulose enzymatic hydrolysis and the sugar fermentation are undertaken by separated. It has the advantage that both processes are in optimal conditions. While enzymes responsible for cellulose hydrolysis work more appropriately at temperatures near to $50^{\circ} \mathrm{C}$ (Pérez et al., 2002; Yu et al., 2003; Fernández et al., 2011), the fermentative microorganisms, generally yeasts, have an optimal culture temperature of $37^{\circ} \mathrm{C}$ (Xu et al., 2009). The main disadvantage is that glucose and cellobiose released by the enzymatic hydrolysis can inhibit the enzymes implicated in both bioprocesses, leading to low yields (Martínez et al., 2000; Chartchalerm et al., 2007).

The aim of the hydrolysis of cellulose is to break it to get free glucose units. This process is catalyzed by an enzyme family known as cellulases. Cellulases are produced by fungus like Trichoderma ressei and Aspergillus niger (Saha et al., 2005, 2006; Linde et al., 2008; Pedersen et al., 2009) and bacteria like Clostridium cellulovorans (Arai et al, 2006; Talebnia et al., 2010). There are at least three kind of cellulases that act synergistically, endoglucanases, exoglucanases and $\hat{a}$-glucosidases. Endoglucanases attack low cristalinity regions of the fiber leaving free ends from which exoglucanases degrade the molecule releasing cellobiose units. It is from this molecule that glucose is produced by $\hat{a}$-glucosidase. Cellulose hydrolysis depends on many factors, including reactives and products concentration, enzymatic activity and reaction conditions. Cellobiose acts like an inhibitor of many cellulases, exo and endoglucanases; on the other hand, $\hat{a}$-glucosidase is inhibited by glucose (Galbe at al., 2002; Rabinovich et al., 2002; Talebnia et al., 2010). Material pretreatment and factors like culture media, $\mathrm{pH}$ and hydrolysis temperature are also determinant for cellulose hydrolysis. Most cellulases show optimum activity between $\mathrm{pH} 4-5$ and $44-55^{\circ} \mathrm{C}$ (Galbe et al., 2002). Yeast species from the genera Candida, Saccharomyces and Kluyveromyces are commonly used (Oh et al., 2000; Zaldivar et al., 2001; Dien et al., 2003; Chartchalerm et al., 2007). Saccharomyces cerevisiae is the most used inindustrial bioethanol production (Valdivieso, 2006).

Looking to improve costs, minimize the inhibitory effects, and enhance yields, strategies like Simultaneous Saccharification and Fermentation (SSF) have been used, where hydrolysis and fermentation are performed in the same reactor at the same time (Mutreja et al., 2011). The main advantages are that the operation time is reduced from six to three days and that the glucose inhibitory effects are minimized (Mejía et al., 2009). The main problem is to choose the work temperature. One of the critical points could be focused in finding yeast strains thermotolerants or thermophilics, able to resist extreme culture conditions in terms of temperature (Mariscal Moreno, 2011). Another factor to take into account is wood concentration, due to the fact that lignin removal produces phenols that can have different effects on the yeast (Pérez et al., 2002; Cuervo et al., 2009; Mariscal Moreno, 2011).

Looking for studying the behavior at $40^{\circ} \mathrm{C}$ of a commercial cellulase, Eucalyptus sawdust saccharification was performed under two $\mathrm{pH}$ conditions. With the aim to evaluate the bioethanol production from Eucalyptus wood, a strategy combining saccharification and Simultaneous Saccharification and Fermentation (SSF) was carried out at $40{ }^{\circ} \mathrm{C}$ with a thermotolerant Saccharomyces cerevisiae with different substrate and inoculum concentrations, and different nitrogen sources. At last, the process was carried out in optimal conditions with Saccharomyces cerevisiae M522 and SacSV-10.

Revista Árvore. 2017;41(4):e410413 


\section{MATERIALS AND METHODS}

\subsection{Raw material}

Previously treated raw material (Eucalyptus grandis) was obtained from ALUR, Uruguay.

The composition of the lignocellulosic material after the pretreatment process was: cellulose $50 \%$, hemicellulose $26 \%$ and lignin $24 \%$.

\subsection{Enzymes}

A commercial enzymatic complex (Sunson, 55 FPU/g) was assayed at $1 \% \mathrm{w} / \mathrm{v}$.

\subsection{Microorganism}

The performance of two strains of Saccharomyces cerevisiae, M522 (ATCC) and the mutantSacSV-10 (Vázquez et al., 2012) was evaluated. The mutant strain was obtained by gamma radiation in the Laboratory of Biochemistry and Biotechnology, Faculty of Sciences, CIN. The strains were freeze-dried and kept frozen at $-80{ }^{\circ} \mathrm{C}$ and $-20^{\circ} \mathrm{C}$. The strains were reactivated by means of a YPD agar passage, cultured at $37^{\circ} \mathrm{C}$ overnight, then a pre-inoculum and an inoculum (from the pre-inoculum) were made in YPD broth with an initial cell concentration of $10^{6}$ $\mathrm{cfu} / \mathrm{mL}$ and incubated in the same conditions.

\subsection{Saccharification assay}

The performance of a commercial cellulose at an intermediate temperature between the optimum for enzymatic saccharification and yeast fermentation $\left(40^{\circ} \mathrm{C}\right)$ was assayed. This temperature was chosen for the Simultaneous Saccharification and Fermentation process. Two $\mathrm{pH}$ conditions were also evaluated.

Flasks containing $2.5 \mathrm{~g}$ of previously treated solid substrate and $50 \mathrm{~mL}$ of acetate buffer $\mathrm{pH} 5.0$ or citrate buffer $\mathrm{pH} 3.0$, were sterilized in autoclave at $121^{\circ} \mathrm{C}$ for $15 \mathrm{~min}$. Then $0.5 \mathrm{~g}$ of enzyme were added and the flasks were incubated at $40{ }^{\circ} \mathrm{C}$ for 5 days. Aliquots were taken at different times and total reducing sugar concentration was measured.

\subsection{Evaluation of different nitrogen sources and initial inoculum concentration in a system treated with a commercial cellulase}

A fermentation of culture medium obtained from wood saccharification with Sunson cellulase was undertaken. The culture medium was supplemented with ammonium sulphate $(500 \mathrm{mg} / \mathrm{l})$ or bacteriological peptone (10 g/l) as nitrogen sources, and initial inoculum concentrations were $5 \% \mathrm{v} / \mathrm{v}$ and $10 \% \mathrm{v} / \mathrm{v}$. Fermentations were carried out at 40 ÚC for $48 \mathrm{~h}$ under anaerobic conditions without shaking. Samples were taken at different times to evaluate biomass content by plate counting technique and sugar concentration by DNS technique (Chaplin, 1986).

\subsection{Evaluation of different substrate concentrations in the combined process}

The initial hydrolysis was carried out in $500 \mathrm{~mL}$ Erlenmeyer flasks with a wood concentration of 10 , 20 and $60 \mathrm{~g} / \mathrm{L}(5,10$ and $30 \mathrm{~g} / \mathrm{L}$ of cellulose concentration) in acetate buffer $\mathrm{pH} 4.8$. The enzyme concentration was $1 \% \mathrm{w} / \mathrm{v}$. The flasks were incubated in an oven at $50^{\circ} \mathrm{C}$ without shaking for $48 \mathrm{~h}$. Temperature was then set at $40^{\circ} \mathrm{C}$, and fermentation was started without stopping saccharification, with an initial yeast concentration of $10^{6}$ cells $/ \mathrm{mL}$ and supplemented with ammonium sulphate $(500 \mathrm{mg} / \mathrm{L})$ as nitrogen source. Assays were performed by triplicate. Samples were taken at different times to determine biomass content, sugar and ethanol concentrations. Flasks without inoculum were used as controls.

\subsection{Saccharification followed by Simultaneous Saccharification and Fermentation (SSF) in optimal conditions}

The hydrolysis was carried out in $500 \mathrm{~mL}$ Erlenmeyer flasks with a cellulose concentration of $5 \mathrm{~g} / \mathrm{L}$ in acetate buffer $\mathrm{pH}$ 5.0. The cellulase enzyme concentration was $1 \% \mathrm{w} / \mathrm{v}$. The flasks were incubated at $50{ }^{\circ} \mathrm{C}$ without shaking. Fermentation assays with M522 were performed at $37^{\circ} \mathrm{C}$ while for SacSV-10 strain they were performed at $40^{\circ} \mathrm{C}$, with an initial yeast concentration of $10^{6} \mathrm{cells} / \mathrm{mL}$ and supplemented with ammonium sulfate $(500 \mathrm{mg} / \mathrm{L})$ as nitrogen source. Inoculum was added $48 \mathrm{~h}$ after the beginning of the saccharification without stopping the initial process, transforming this into a Simultaneous Saccharification and Fermentation process. Assays were performed by triplicate. Samples were taken at different times to determine biomass content, sugar and ethanol concentrations. Flasks without inoculum were used as controls.

\subsection{Analytical methods}

Total reducing sugars were determined by the Dinitro Salicylic Acid (DNS) method (Chaplin, 1986). The alcohol

Revista Árvore. 2017;41(4):e410413 
content was determined by the potassium dichromate technique (Chartchalerm et al., 2007). Cell concentration during inoculum development and fermentation was determined by plate counting in Yeast Potato Dextrose Agar (YPD, Merck) culture medium. The plates were incubated at $35^{\circ} \mathrm{C}$ for $72 \mathrm{~h}$.

\subsection{Statistical analysis}

Results were compared with a variance analysis (ANOVA) under the null hypothesis that there are not significant differences between assays (Sokal, 1998). A probability level of $\mathrm{p}=0.05$ and the program Past (version 2.17) (Hammer, 2001) were used.

\section{RESULTS}

\subsection{Saccharification analysis}

Saccharification at $40^{\circ} \mathrm{C}$ showed a peak of reducing sugars production of $1.5 \mathrm{~g} / \mathrm{L}$ at $100 \mathrm{~h}$ (Figure 1). Initially, $1 \mathrm{~g} / \mathrm{L}$ of sugar corresponded to the enzyme carrier. If the results are compared, it is observed that at $40{ }^{\circ} \mathrm{C}$, the enzyme worked more adequately at pH 5.

\subsection{Evaluation of different nitrogen sources and initial inoculum concentration in a system treated with a commercial cellulase}

Figure 2 shows that under all the conditions assayed a slight increase in biomass is produced, in less than the half of an order, do not exceeding $10^{7} \mathrm{cfu} / \mathrm{mL}$. The use of Sunson cellulase produces $5 \mathrm{~g} / \mathrm{L}$ of glucose at the beginning of fermentation. Better results were

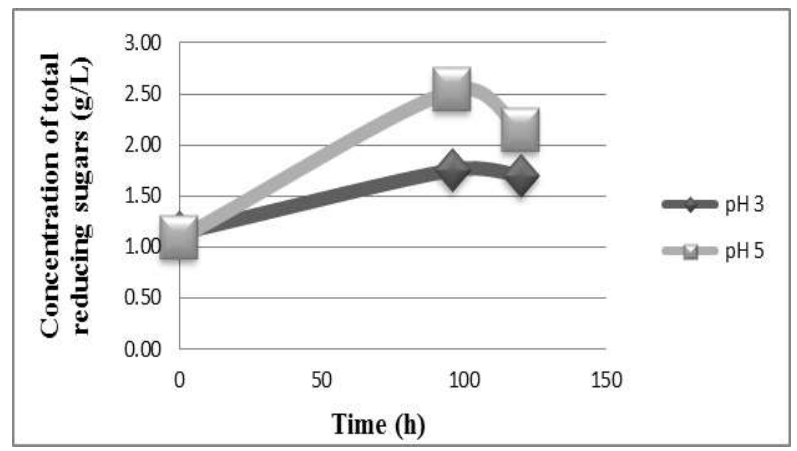

Figure 1 - Reducing sugar concentration at different saccharification times, at $40^{\circ} \mathrm{C}$ and different $\mathrm{pH}$ conditions.

Figura 1-Concentração de açúcares redutores totais a diferentes tempos de sacarificação, a $40^{\circ} \mathrm{Ce}$ em condições diferentes de $\mathrm{pH}$. obtained with an initial inoculum concentration of 10 $\% \mathrm{v} / \mathrm{v}$ and $500 \mathrm{mg} / \mathrm{L}$ of ammonium sulphate. Similar results were obtained with strain M522.

\subsection{Evaluation of different substrate concentrations in the combined process}

From the obtained results of biomass variation over time during the process, it was seen an increase in one order of $\mathrm{cfu} / \mathrm{mL}$ in $25 \mathrm{~h}$ of SSF when $5 \mathrm{~g} / \mathrm{L}$ of cellulose were used (Figure 3 ).

Figure 4 shows alcohol results. It can be seen that after $100 \mathrm{~h}$ of process ( $50 \mathrm{~h}$ of SSF) a maximum in ethanol production is reached, with $0.24 \% \mathrm{v} / \mathrm{v}$ for the assay with $5 \mathrm{~g} / \mathrm{L}$ of cellulose and $0.15 \% \mathrm{v} / \mathrm{v}$ with $30 \mathrm{~g} / \mathrm{L}$ of cellulose. Those results correspond to reaction yields of $73 \%$ and $11 \%$ respectively. Similar results were obtained with strain M522.

\subsection{Saccharification followed by Simultaneous Saccharification and Fermentation (SSF) in optimal conditions}

The initial sugar concentration was $0.5 \mathrm{~g} / \mathrm{L}$. Previous to inoculation (after $48 \mathrm{~h}$ of saccharification) it increased to $2.5 \mathrm{~g} / \mathrm{L}$. Yeast biomass increased to $3.0 \times 10^{6}$ in the first $3.5 \mathrm{~h}$ of fermentation using the M522 strain. When SacSV-10 strain was used, the biomass increase was almost of one order in $23 \mathrm{~h}$ of fermentation, reaching a concentration of $9.8 \times 10^{6} \mathrm{cfu} / \mathrm{mL}$. After this time, the yeast decreased its concentration remaining in the same order and the sugar concentration was $0.54 \mathrm{~g} / \mathrm{L}$ at the end of the process when using SacSV-10, whereby it was suggested that remaining sugars are not fermentable sugars.

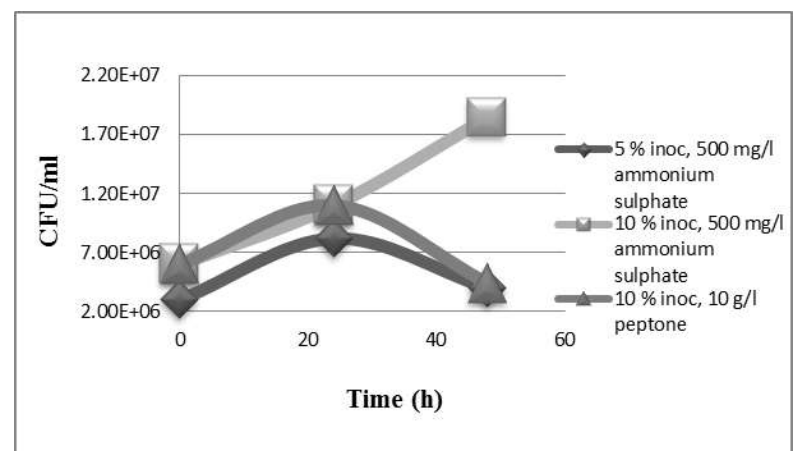

Figure 2-SacSV-10 biomass produced in the fermentation of wood.

Figura 2 - Biomassa produzida de SacSV-10 em fermentação de madeira

Revista Árvore. 2017;41(4):e410413 


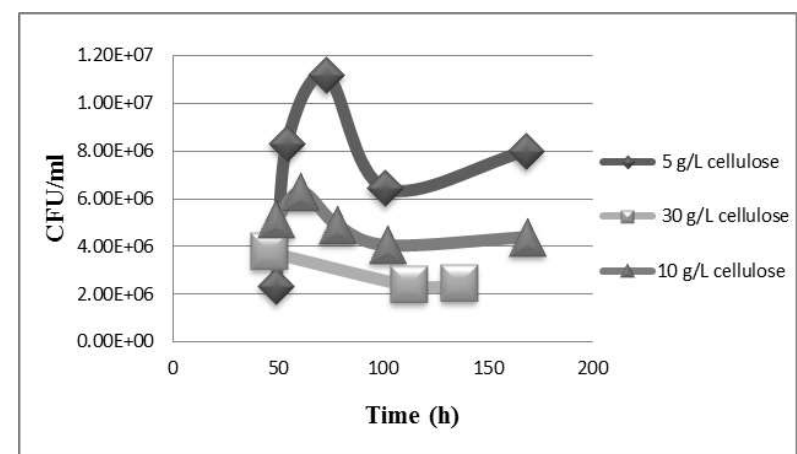

Figure $3-\mathrm{SacSV}-10$ biomass produced at different wood concentrations.

Figura 3-Biomassa de SacSV-10 produzido em concentrações diferentes de madeira.

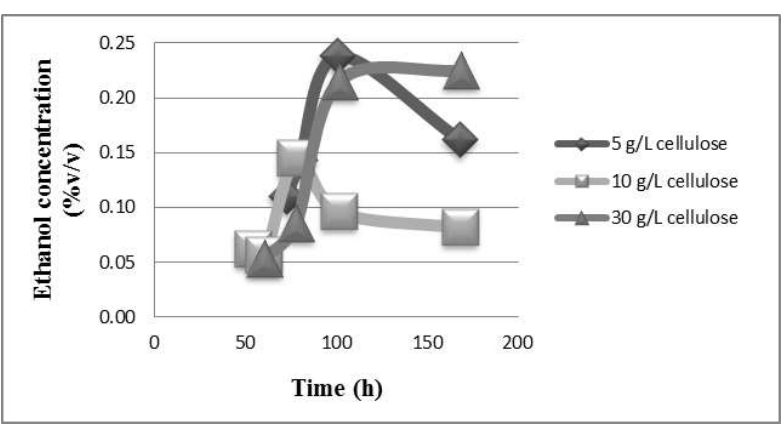

Figure 4-Ethanol produced with different wood concentrations inoculated with SacSV-10.

Figura 4-O etanol produzido em concentrações diferentes de madeira inoculadas com SacSV-10.

Table 1 shows the results for alcohol production and other fermentation parameters like specific growth rate and the relation between cfu at the begining and the end of the process. The maximum ethanol production, $0.23 \%(\mathrm{v} / \mathrm{v})$, occurred at $60 \mathrm{~h}$ of SSF process with M522 strain. When SacSV-10 strain was used, the ethanol concentration was $0.24 \%(\mathrm{v} / \mathrm{v})$ in $100 \mathrm{~h}$ of SSF process. A decreasing in the ethanol concentration was observed in both cases, that could be due to its evaporation or its consumption by the yeast. The results show that SacSV-10 and M522 produces the same amount of alcohol but with different kinetic.

\section{DISCUSSION}

According to the saccharification assays performed at $40{ }^{\circ} \mathrm{C}$, Sunson cellulase produces more free glucose at $\mathrm{pH} 5$, reaching a maximum of $1.5 \mathrm{~g} / \mathrm{L}$, that corresponds to a conversion percentage of cellulose to glucose
Table 1 - Fermentation parameters

Tabela 1 - Parâmetros de fermentações.

\begin{tabular}{lccc}
\hline Strain & $\begin{array}{c}\text { N/No at the } \\
\text { end of the } \\
\text { log phase }\end{array}$ & $\begin{array}{c}\text { Specific } \\
\text { growth } \\
\text { rate } \mu(\mathrm{h}-1)\end{array}$ & $\begin{array}{c}\text { Maximum } \\
\text { ethanol } \\
\text { produced } \\
\%(\mathrm{v} / \mathrm{v})\end{array}$ \\
\hline SacSV-10 & 4.48 & 0.202 & 0.24 \\
M522 & 2.66 & 0.222 & 0.23 \\
\hline
\end{tabular}

of $30 \%$ with an enzymatic activity of $11 \mathrm{FPU} / \mathrm{g}$ (solid), similar to other authors results (Camesasca, 2013).

From the obtained results with the SacSV-10 strain, it is advisable to work with an initial inoculum concentration of $10 \% \mathrm{v} / \mathrm{v}$. The adding of $500 \mathrm{mg} / \mathrm{lof}$ ammonium sulphate would allow better results in biomass production rather than the addition of yeast extract that is an expensive supplement to use at industrial level.

In the assays with different wood concentrations, the cellulase and yeasts worked adequately at $40{ }^{\circ} \mathrm{C}$ using $5 \mathrm{~g} / \mathrm{L}$ of cellulose. The yeast SacSv-10 was not inhibited by phenols present in the culture media using a wood concentration of $10 \mathrm{~g} / \mathrm{L}$, but when the solids concentration was increased, the bioprocess yield was compromised due to some kind of yeast inhibition or saccharification enzymes inhibition. Therefore, to increase the enzymatic hydrolysis yield with high concentrations of substrate, strategies as sequential addition of solids can be used (Linde et al., 2006).

When a wood concentration of $10 \mathrm{~g} / \mathrm{L}$ was used with the SacSV-10 strain, an alcohol concentration of $0.24 \%(\mathrm{v} / \mathrm{v})$ was obtained, which corresponds to a yield of $73.6 \%$. This kind of process, that includes Simultaneous Saccharification and Fermentation, does not allow to estimate parameters like sugar consumption rate because glucose is consumed as it is produced.

When the process was carried out in optimal conditions with M522 and the mutant strain, the reaction yields were $71.5 \%$ and $73.6 \%$ respectively. The end of the exponential phase occurred about $60 \mathrm{~h}$ after the beginning of the process. The ethanol concentrations obtained were $0.23 \% \mathrm{v} / \mathrm{v}$ and $0.24 \% \mathrm{v} / \mathrm{v}$ respectively. The amount of alcohol obtained with the SacSV-10 strain corresponds to $180 \mathrm{mg}$ of ethanol per g of wood. This result is similar to that obtained by other authors in lignocellulosic materials as well as other sources of raw materials such as elephant grass (Juri, 2011; Camesasca, 2013). 


\section{CONCLUSIONS}

The commercial cellulase (Sunson) showed encouraging results for its use in SSF process because it performed properly at $40^{\circ} \mathrm{C}$, an intermediate temperature between the optimum for enzymatic saccharification and yeast fermentation (Olofsson et al., 2008).

According to the obtained results, the SSF process, greatly improves the amount of fermented sugar, by approx. $50 \%$.

The yeast strains assesed did not suffer inhibition by phenols present in the culture media at $10 \mathrm{~g} / \mathrm{L}$ of wood concentration, this would allow their incorporation into a bioprocess of alcohol production from Eucalyptus $s p$. The studied properties of the mutant strain provide added value to it, which pose new challenges to national companies dedicated to the production and sale of inputs for bioethanol industry.

Due to the high cost for the national industry of importing microorganisms used in fermentation, it is of great importance to have native or nationally produced strains, that can be incorporated into production processes and thereby reducing costs.

Future efforts will be focused on increasing the amount of wood used with the aim to improve the bioprocess profitability.

\section{REFERENCES}

Arai,T, Kosugi A, Chan H, Koukiekolo R, Yukawa H, Inui $\mathrm{M}$ et al. Properties of cellulosomal family 9 cellulases from Clostridium cellulovorans. Applied Microbiology and Biotechnology. 2006;71:654-60.

Camesasca L. Producción de bioetanol combustible a partir de pasto elefante : estudio de la hidrólisis enzimática y fermentación [tesis] Montevidéu: Universidad de la República, Facultad de Ciencias; 2013.

Carreón O, Ramos A, Centeno S, Leal L, Martínez A, Fernández M.. Etanol Carburante. BioTecnología. 2009;13(3):79-102.

Cuervo C, Folck J, Quiroz R. Lignocelulosa como fuente de azúcares para la producción de etanol. BioTecnología. 2009;13(3):11-25.

Chaplin M. Monosaccharides. "Carbohydrate analysis: a practical approach”. Oxford: Chaplin \& Kennedy; 1986. 36p.
Chartchalerm I, Tanawut T, Thikamporn K, Ponpitak P, Virapong P.. Appropriate technology for the bioconversion of water hyacinth (Eichhorniacrassipes) to liquid ethanol: future prospects for community strengthening and sustainable development. EXCLI Journal. 2007;(6):167-76.

Dien B, Cotta M, Jeffries T. Bacteria engineered for fuel ethanol production current status. Applied Microbiology and Biotechnolnogy. 2003;63:258-66.

Fernández J, Lucas H, Ballesteros M. Energías renovables para todos: Biocarburantes. Haya Comunicación; 2011.20p.

Galbe M, Zacchi G. A review of the production of ethanol from softwood. Applied Microbiology and Biotechnology. 2002;59: 618-28.

Haghighi S, Hossein A, Tabatabaei M, Salehi G, Hassan G, Gholami M, et al. Lignocellulosic biomass to bioethanol, a comprehensive review with a focus on pretreatment. Renewable and Sustainable Energy Reviews. 2013;27:77-93.

Hammer O, Harper D, Ryan P. PAST: paleontological statistic software package for education and data analysis. Palaeontologia Electronica. 2001;4(1):1-9.

Juri S. Sacarificación y fermentación simultánea para la producción de bioetanol de segunda generación, mediante pretratamientos alternativos: líquidos iónicos reciclados y hongos de pudrición blanca. local: Universidad de Chile, Facultad de Ciencias Físicas y Matemáticas; 2011.

Leonowicz A, Matuszewska M, Luterek J, Ziegenhagen D, Wojtas-Wasilewska M, Cho N, Hofrichter P, Rogalski J. Biodegradation of lignin by white-rot fungi. Fungal Genetics and Biology. 1999(27):175-85.

Linde M, Galbe M, Zacchi G. Steam pretreatment of acid-sprayed and acid soaked barley straw for production of ethanol. Applied Biochemistry and Biotechnology. 2006;129-132:546-62.

Linde M, Jakobsson E-L, Galbe M, Zacchi G. Steam pretreatment of diluteH2SO4-impregnated wheat straw and SSF with low yeast and enzyme loadings for bioethanol production. Biomass and Bioenergy. 2008(32):326-32.

Revista Árvore. 2017;41(4):e410413 
Mariscal Moreno JP. Evaluación y selección de microorganismos para la producción de etanol a nivel industrial. Bogotá: Universidad Nacional de Colombia; 2011.99p.

Martínez A, Rodriguez M, York S, Preston J, Ingram L. Effects of $\mathrm{Ca}(\mathrm{OH}) 2$ treatments ("overliming") on the composition and toxicity of bagasse hemicellulose hydrolysates. Biotechnology and Bioengineering. 2000;69(5):526-36.

Mejía L, Albán D, Murcia N, Cuervo R, Durán J. Hidrólisis y fermentación alcohólica simultánea (HFS) del residuo agroindustrial del mango común (Mangifera indica L) utilizando levaduras Saccharomyces cerevisiae spp y cepa recombinante RH 218. Revista Científica Guillermo de Ockham. 2009;7(2):51-64.

Mutreja R, Das D, Goyal D, Goyal A. Bioconversion of AgriculturalWaste to Ethanol by SSF Usin Recombinant Cellulase from Clostridium thermocellum. Enzyme Research. 2011; 2011:1-6

Oh K, Kim S, Jeong Y, Hong S. Bioconversion of cellulose into ethanol by nonisothermal simultaneous saccharification and fermentation. Applied Biochemistry and Biotechnology. 2000(89):15-30.

Olofsson K, Bertilsson M, Lidén G.. A short review on SSF - an interesting process option for ethanol production from lignocellulosic feedstocks. Biotechnology for Biofuels. 2008(7):1-14.

Ortiz M. Aproximaciones a la comprensión de la degradación de la lignina. Orinoquia. 2009;13(2):13744.

Pedersen M, Meyer A. Influence of substrate particle size and wetoxidation on physical surface structures and enzymatic hydrolysis of wheatstraw. Biotechnology Progress. 2009(25):399-408.

Pérez J, Muñoz-Dorado A, De la Rubia T, Martinez E. Biodegradation and biological treatments of cellulose, hemicellulose and lignin: an overview. International microbiology. 2002;5:53-62.

Rabinovich M, Melnik M, Boloboba A. Microbial cellulases (review). Applied Biochemistry and Microbiology. 2002(38):305-21.

Saha B, Cotta M.. Ethanol production from alkaline peroxidepretreated enzymatically saccharified wheat straw. Biotechnology Progress. 2006(22):449-53.

Saha B, Iten L, Cotta M, Wu Y. Dilute acid pretreatment, enzymatic saccharification and fermentation of wheat straw to ethanol. Process Biochemistry. 2005(40):3693-700.

Sánchez O, Cardona C. Producción biotecnológica de alcohol carburante I: obtención a partir de diferentes materias primas. Interciencia. 2005;30(11):671-8.

Sokal R, Rohlf F. Biometry: the principles and practice of statistics in biological research. $3^{\text {rd }}$.ed. New York: Freeman and Co; 1998. 896p.

Valdivieso M. Obtención y caracterización de cepas de Saccharomyces cerevisiae productoras de glutatión. Granada: Editorial de la Universidad de Granada; 2006. 215p.

Vázquez S, Buxedas L, Lopretti M. Obtención de cepas de Saccharomyces cerevisiae por"-irradiación tolerantes a condiciones extremas de cultivo para la producción de bioetanol. INNOTEC. 2012(7):64-8.

Talebnia F, Karakashev D, Angelidaki I. Production of bioethanol from wheat straw: An overview on pretreatment, hydrolysis and fermentation. Bioresource Technology. 2010(101):4744-53.

Xu Q, Singh A, Himmel M. Perspectives and new directions for the production of bioethanol using consolidated bioprocessing of lignocellulose. Current Opinion in Biotechnology. 2009;20:364-71.

Yu Z, Zhang H.. Pretreatment of cellulose pyrolysate for ethanol production by Saccharomyces cerevisiae, Pichia sp. YZ1 and Zymomonas mobile. Biomass Bioenergy. 2003;24:257-63.

Zaldivar J, Nielsen J, Olsson L. Fuel ethanol production from lignocellulose: a chalenge for metabolic engineering and process integration. Appl. Microbiol. Biotechnol. 2001(56):17-34.

Zhua W, Houtmanb C, Zhub J, Gleisnerb R, Chenc K. Quantitative predictions of bioconversion of aspen by dilute acid and SPORLpretreatments using a unified combined hydrolysis factor (CHF). Process Biochemistry. 2012(47):785-91. 